\title{
In-depth understanding of Pearson syndrome arising from a novel large mitochondrial DNA deletion in an infant case
}

\author{
Rui Liu ${ }^{1}$, Gui-Ling $\mathrm{Mo}^{2}$, Yuan-Zong Song ${ }^{1}$ \\ ${ }^{1}$ Department of Pediatrics, The First Affiliated Hospital, Jinan University, Guangzhou, China; ${ }^{2}$ Guangzhou Kingmed Center for Clinical Laboratory, \\ Guangzhou, China \\ Correspondence to: Professor Yuan-Zong Song, MD, PhD. Department of Pediatrics, The First Affiliated Hospital, Jinan University, Guangzhou \\ 510630, China. Email: songyuanzong@vip.tom.com. \\ Response to: Finsterer J. Comprehensive clinical and genetic work-up of patients carrying single mtDNA deletions is warranted. Transl Pediatr \\ 2021;10:1972-3.
}

Submitted Mar 22, 2021. Accepted for publication Jun 07, 2021.

doi: $10.21037 /$ tp-21-199

View this article at: https://dx.doi.org/10.21037/tp-21-199

Thanks for letting us have the comments and concerns raised by Finsterer on our article entitled "Identification of a novel large deletion of the mitochondrial DNA in an infant with Pearson syndrome: a case report" which was published on Transl Pediatr [2021;10(1):204-208]. The comments and concerns are really valuable for our in-depth understanding and subsequent investigation of mitochondrial diseases.

Firstly, heteroplasmy is defined as the presence of a mixture of more than one type of an organellar genome within a cell or tissue (1). High-throughput sequencing results of mitochondrial DNA (mtDNA) by using blood sample of our patient suggested that the heteroplasmy rate of the mtDNA deletion was about $73 \%$. However, the heteroplasmy rate in other tissues or organs remains unclear due to lacking relevant samples.

Secondly, biochemical investigations of the respiratory chain were not carried out due to technical limitations. Given the fact that the infant suffered from chronic hepatomegaly, liver dysfunction, anemia and lactic acidosis over 1 year and so many genes encoding for subunits of complex-I and tRNAs were deleted, the function of the respiratory chain complex was believed to be impaired, at least in the liver and bone marrow.

Thirdly, the comment on muscle biopsy was believed to be reasonable, but the patient was just an outpatient in our hospital, and muscle biopsy was not performed due to lacking of the relevant informed consent from the parents.

Fourthly, we absolutely agree that early recognition of multisystem involvement was crucial for initiating early symptomatic treatment and thus improving quality of life and outcome of an individual patient, and that is why close follow-up in our clinic was suggested. We will update this case report if involvement of the brain, eyes, ears, endocrine organs, heart, kidneys, muscle or peripheral nerves is observed in the future.

Finally, we do need to add and clarify the following information. When aged 16 days, the patient underwent urinary organic acid analysis in another hospital, which revealed elevated 4-hydroxyphenyllactic acid and 4-hydroxyphenylpyruvate. His liver was normal in size and texture at the age of 18 hours, but hepatomegaly was noticed since his age 1 month as described in his medical records, and was confirmed at his referral to our clinic when aged 13 months.

Once again, the authors cordially appreciate Finsterer for sharing his expertise in mitochondrial diseases, and any further comments and concerns on our article will be welcome.

\section{Acknowledgments}

Funding: None.

\section{Footnote}

Provenance and Peer Review: This article was a standard submission to the journal. The article did not undergo external peer review. 
Conflicts of Interest: All authors have completed the ICMJE uniform disclosure form (available at https://dx.doi. org/10.21037/tp-21-199). The authors have no conflicts of interest to declare.

Ethical Statement: The authors are accountable for all aspects of the work in ensuring that questions related to the accuracy or integrity of any part of the work are appropriately investigated and resolved.

Open Access Statement: This is an Open Access article distributed in accordance with the Creative Commons Attribution-NonCommercial-NoDerivs 4.0 International
License (CC BY-NC-ND 4.0), which permits the noncommercial replication and distribution of the article with the strict proviso that no changes or edits are made and the original work is properly cited (including links to both the formal publication through the relevant DOI and the license). See: https://creativecommons.org/licenses/by-nc-nd/4.0/.

\section{References}

1. Sobenin IA, Mitrofanov KY, Zhelankin AV, et al. Quantitative assessment of heteroplasmy of mitochondrial genome: perspectives in diagnostics and methodological pitfalls. Biomed Res Int 2014;2014:292017.
Cite this article as: Liu R, Mo GL, Song YZ. In-depth understanding of Pearson syndrome arising from a novel large mitochondrial DNA deletion in an infant case. Transl Pediatr 2021;10(7):1972-1973. doi: 10.21037/tp-21-199 